\title{
UNUSUAL AERIAL DISPLAY OF RED-TAILED HAWK
}

ROBERT W. NERO, Box 24, 1495 St. James Street, Winnipeg, Manitoba. R3H OW9

Aerial antics associated with courtship displays of raptors have long fascinated observers. The American poet Walt Whitman, for example, in "The Dalliance of the Eagles" rhapsodized thusly (in part):

The rushing amorous contact high in space together,

The clinching, interlocking claws, a living

fierce, gyrating wheel,

Four beating wings, two beaks, a

swirling

mass tight grappling,

In tumbling, turning, clustered loops, straight downward falling...

For the Red-tailed Hawk, Bent noted: "The birds are apparently in pairs when they arrive on their breeding grounds, but they indulge in nuptial demonstrations more or less all through the nesting season. I have seen a pair of these hawks, in May when there were young in the nest, indulging in their joint flight manoeuvres high above the woods where the nest was located; they soared in great circles, crossing and recrossing each other's paths, sometimes almost touching, and mounting higher and higher until almost out of sight; finally one partially closed its wings and made a thrilling dive from a dizzy height, checking its speed just before it reached the wood."1

According to Palmer, the female's reaction to the male's close approach or contact as he touches her back with his dangling feet in flight is usually passive, but "sometimes she turns over and presents her talons upward! ... Two birds cartwheeling earthward with talons interlocked occasionally are seen in spring: usually 1 [one] is evidently a territory holder and the other is an interloper. When they are about to crash, they disengage." ${ }^{3}$

Nothing I have read or seen, however, prepared me for a performance observed on 24 April 1993. Tara Evans and I were watching for migrating hawks at a site in the Pembina River Valley northeast of Windygates, Manitoba. Because of a strong, cold wind from the north, we were sitting in the car on a terrace on the south side of the valley. Not many raptors were moving; those few that came by, however, passed near us as they headed northwest up the valley. Whenever we saw a hawk, we jumped out to look with binoculars. It was sunny and the birds were conspicuous. At 4:00 p.m., a pair of Red-tailed Hawks, apparently local birds, provided some spectacular flying. One bird, presumably the male, repeatedly soared much higher than the other, far above the valley, then hurtled down upon the other bird. On at least four occasions, at the last moment the lowermost bird rolled over onto its back and the two birds grabbed each other's feet, flapping momentarily before letting go. Twice we saw them drop together more than 100 $\mathrm{m}$, both times going out of sight behind trees that blocked our view of 
the river down below. In each case, it was a few minutes before the birds came back into sight. The first time, they fell with a flurry of wings. The second time, with feet locked, they dropped straight down while lying on their backs with wings extended. At the same time, perhaps owing to the force of the wind, they were turning while descending, rotating like the blades of a helicopter. We estimated that they made two to three revolutions per second as they fell. During this dramatic and novel manoeuvre both of us shouted: "They're upside down!"

Once before l'd seen a bird flying upside down. That was a courting Common Raven that soared upwards into the wind over a cliff to reach its mate: "Several times the lower bird rose rapidly beneath the other and then when near suddenly flipped over onto its back for a brief moment with wings fully outspread, reaching up with its feet toward the dangling feet of the upper bird - an astonishing feat since both birds continued to soar upwards." 2 The aerodynamics of birds in upsidedown position are beyond my comprehension, but experienced pilots fly upside down with ease. Why not birds?

The two Red-tailed Hawks soon flew into nearby woods where they alternately perched and flew after each other, as if they had an interest in nesting. Dorothy Schritt, who with her husband, Al, annually monitors migrant raptors at this site - where as many as 3,100 Red-tailed Hawks have been seen in one day - noted that one resident red-tail seen here regularly has a broken primary, a feature not evident on either of our two birds. After I described the exciting aerial gymnastics we'd seen, Dorothy aptly pointed out that if there had been good numbers of raptors migrating, we might have missed a moment of splendor.

1. Bent, A.C. 1937. Life histories of North American birds of prey. Part 1 , U.S. Natl. Mus. Bull. 167. Reprinted by Dover Publications. 1961. 409 pp.

2. Nero, R.W. 1963. Birds of the Lake Athabasca region, Saskatchewan. Spec. Pub. No. 5, Sask. Nat. Hist. Soc. $143 \mathrm{pp}$.

3. Palmer, R.S. 1988. Handbook of North American birds. Vol. 5. Yale University Press, New Haven, 465 pp.

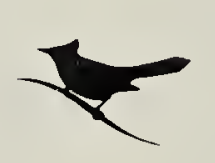

Robin is one of the most native and democratic of our birds; he is one of the family, and seems much nearer to us than those rare, exotic visitants, as the orchard starling or the rose-breaster grosbeak, with their distant high-bred ways. Hardy, noisy, frolicsome, neighborly, and domestic in his habits, strong of wing and bold in spirit, he is the pioneer of the thrush family, and well worthy of the finer artists whose coming he heralds and in a measure prepares us for. John Burroughs. 1895. Wake Robin. Houghton Mifflin, Boston. 